\title{
Isokinetic trunk strength in the teenagers with and without low-back pain: a comparative study
}

\author{
JC Bernard", A Pujol, S Boudokhane, J Deceuninck, E Chaleat-Valayer \\ From 8th International Conference on Conservative Management of Spinal Deformities and SOSORT 2011 \\ Annual Meeting \\ Barcelona, Spain. 19-21 May 2011
}

\section{Objectives}

To evaluate isokinetic trunk strength in low-back pain (LBP) teenagers, its relations with the clinical measures, and comparison analysis with healthy teenagers.

\section{Materials and methods}

This study has included two groups of 22 LBP and 22 healthy teenagers, aged 11-13 years. We have measured the isokinetic trunk strength in each group on the Cybex trunk extension/flexion machine.

\section{Results}

No significant difference was found between isokinetic peak torque, total work and mean power in extension and flexion in the two groups. Other than, the control group had a higher mean power extension in $120^{\circ}$ s than the LBP group with a nearly significant $p$. Significant correlations between isokinetics total work at $120^{\circ}$ in flexion $(r=0,461)$ and in extension $(r=0,475)$ were observed with the body mass index. A high correlation was also found between the total work at $120^{\circ}$ in extension $(r=0,668)$ and the number of hours per week of sport activities. The mean power in extension at $120^{\circ} \mathrm{s}$ was correlated positively $(r=0,453)$ to the lumbar radiological lordosis. The endurance of agonist (flexors) and antagonist (extensors) ratio was high in both populations compared to the expected values in general population $(0,91$ vs 0,89$)$.

\section{Conclusions}

This study reveals no significant difference in the isokinetic trunk strength of both flexors and extensors in the two groups. Based on the results, its interest to study the effect of isokinetic rehabilitation to remove the inhibition at high speed. Isokinetic strength parameters, as measured

Croix Rouge française-CMCR des Massues, Lyon, France in this study, do not seem to explain the occurrence of low back pain among children.

Published: 27 January 2012

doi:10.1186/1748-7161-7-S1-O38

Cite this article as: Bernard et al:: Isokinetic trunk strength in the teenagers with and without low-back pain: a comparative study. Scoliosis 2012 7(Suppl 1):O38.
Submit your next manuscript to BioMed Central and take full advantage of:

- Convenient online submission

- Thorough peer review

- No space constraints or color figure charges

- Immediate publication on acceptance

- Inclusion in PubMed, CAS, Scopus and Google Scholar

- Research which is freely available for redistribution 